\title{
Evaluation of Pregnant and Postpartum Women's Knowledge about Toxoplasmosis in Rio Grande - RS, Brazil
}

\section{Avaliação do conhecimento de gestantes e puérperas sobre a toxoplasmose na cidade do Rio Grande - RS, Brasil}

\author{
Lis Maurente Lehmann ${ }^{1} \quad$ Paula Costa Santos $^{1} \quad$ Carlos James Scaini ${ }^{1}$
}

1 Universidade Federal do Rio Grande, Rio Grande, RS, Brazil

Address for correspondence Lis Maurente Lehmann, Nurse, MSc, Rua. Gen. Osório, S/N - Centro, 96200-400 - Rio Grande, Brasil Rev Bras Ginecol Obstet 2016;38:538-544. (e-mail: lis_leh@msn.com).

\begin{abstract}
Keywords

- toxoplasmosis

- congenital infection

- prenatal
\end{abstract}

Resumo
Introduction Toxoplasmosis a parasitic zoonosis of global distribution, responsible for disorders during gestation can cause fetal death or congenital anomalies.

Objective To evaluate the knowledge of toxoplasmosis among pregnant and postpartum women treated at the University Hospital of the city of Rio Grande, Rio Grande do Sul, Brazil.

Methods This was a cross-sectional study of 100 pregnant and postpartum women at the University Hospital. Participants answered a self-administered questionnaire and gave consent for data relating to serological examinations to be abstracted from their medical records.

Results The proportion of women who received information about toxoplasmosis was higher among those who received care in the private health care system (52.9\%) than among those cared for in the public health care system (25.0\%). Only $55.7 \%$ of women reported having some knowledge about toxoplasmosis. Of these, 53.7\% received information during the prenatal period. However, most participants were unable to answer questions about preventive measures and modes of infection. Of the 100 patients in the study, only 46 underwent serologic testing for toxoplasmosis, $65.2 \%$ of whom tested negative ( $\mathrm{lgG})$.

Conclusion Findings from this study are relevant to the training of health professionals regarding toxoplasmosis education and prevention. Improved education for health care providers and patients can lead to earlier diagnoses and reductions in adverse outcomes.

Introdução A toxoplasmose é um parasita zoonose com distribuição global, responsável por enfermidades durante a gestação que podem causar o óbito do feto ou anomalias congênitas.

Objetivo Avaliar o conhecimento sobre toxoplasmose das gestantes e puérperas atendidas no Hospital Universitário da cidade de Rio Grande, Rio Grande do Sul, Brasil. received

May 12, 2016

accepted

September 27, 2016

published online

December 1, 2016
Copyright $\odot 2016$ by Thieme-Revinter

Publicações Ltda, Rio de Janeiro, Brazil
License terms

(c) (i) $\ominus$ (\$) 10.1055/s-0036-1593970. ISSN 0100-7203. 
Palavras-chave
- toxoplasmose
- infecção congênita
- pré-natal

\begin{abstract}
Método Estudo transversal sobre o conhecimento de 100 gestantes/puérperas no Hospital Universitário. A participação do sujeito da pesquisa consistiu em responder a um questionário autoaplicável e em autorizar o acesso ao seu prontuário e à sua carteira de pré-natal, nos quais foram pesquisados dados referentes aos exames sorológicos realizados.

Resultados $\mathrm{O}$ percentual de mulheres que receberam informações sobre toxoplasmose foi maior nas atendidas no sistema de saúde privado (52,9\%). Somente $55,7 \%$ afirmaram ter algum conhecimento sobre a toxoplasmose. Destas, 53,7\% receberam informação durante o pré-natal. Entretanto, a maioria das participantes não soube responder sobre as medidas preventivas e formas de infecção da toxoplasmose. Das 100 pacientes, apenas 46 realizaram o teste sorológico para toxoplasmose, e destas, $65,2 \%$ apresentaram resultado negativo.

Conclusões Com isso, torna-se relevante o incentivo à educação em saúde dentro das instituições em todos os momentos do pré-natal, e a capacitação dos profissionais frente às gestantes e puérperas acerca da toxoplasmose, abrangendo desde a educação em saúde até a realização do diagnóstico precoce.
\end{abstract}

\section{Introduction}

Toxoplasmosis is a parasitic zoonosis that is found across the globe and is important in pregnancy. ${ }^{1}$ It is estimated that one third of the world's population has antibodies against toxoplasmosis, ${ }^{2}$ and a recent serologic study of pregnant women in the Brazilian state of Paraná found a $59 \%$ prevalence of immunoglobulin (Ig) G antibodies against Toxoplasma gondii. ${ }^{3} \mathrm{~T}$. gondii infection in humans occurs through the ingestion of sporulated oocysts present in food or water, and through the consumption of raw or undercooked meat containing tissue cysts. Transplacental transmission can also occur. ${ }^{4}$

Toxoplasmosis infection during the first trimester of pregnancy may cause miscarriage or serious disorders in the newborn, including increased cranial volume, impaired psychomotor development, chorioretinitis, and cerebral calcifications. ${ }^{5}$ However, infection occurs most frequently in the second and third trimesters of pregnancy. In these cases, $90 \%$ of children born are asymptomatic during the first few years of life. ${ }^{6}$ However, ocular toxoplasmosis is most common among this patient population, and can become symptomatic during the first few months or years of life. ${ }^{7}$

The clinical manifestations of toxoplasmosis are related to the condition of the patient's immune system. ${ }^{4}$ The clinical diagnosis of congenital toxoplasmosis is sometimes inconclusive, as symptoms are similar to those of other diseases. It is therefore necessary to perform laboratory diagnostic testing for $\operatorname{Ig} \mathrm{A}$, IgE, and $\operatorname{IgM}$, as these do not cross the placental barrier. ${ }^{8}$

Serology for the detection of $\operatorname{IgG}$ and $\operatorname{IgM}$ antibodies against $T$. gondii is recommended during prenatal care across most of Brazil. However, preventive guidelines do not include a standard protocol for the detection of these antibodies. ${ }^{9}$ Because the disease is usually asymptomatic, education of pregnant women for prevention is critical in order to reduce infection rates. ${ }^{10,11}$ Accordingly, the present study aimed to assess the knowledge concerning toxoplasmosis and its potential health effects in a sample of pregnant and postpartum women managed at the University Hospital of the city of Rio Grande, Rio Grande do Sul state, Brazil.

\section{Methods}

A cross-sectional study was conducted using a convenience sample of 100 pregnant and postpartum women seen at the maternity ward of the University Hospital Miguel Riet Correa Jr. (HU/FURG), in the city of Rio Grande, between October and December 2013. The sample size was calculated based on a previous study of pregnant women in Pelotas, another city in the same state. ${ }^{12}$ Patients were enrolled in the study after informed consent was obtained from them or from a legal guardian (for patients younger than 18 years). Following enrollment, participants answered a self-administered questionnaire. Results of serological examinations were collected from the medical records.

The self-administered questionnaire was filled out at the HU maternity ward during the hospitalization of the pregnant women due to clinical complications, or during the postpartum period. The questionnaire contained general knowledge questions about toxoplasmosis (transmission, symptoms, treatment, prevention), in addition to sociodemographic fields. The questionnaires were double entered using Epidata (EpiData Association, Odense, Denmark). Data analysis was performed using Epi Info version 6.8 (Centers for Disease Control and Prevention [CDC], Atlanta, Georgia, US).

This study met the ethical standards described in resolution 466/12 of the Brazilian National Health Council (BNHC). The study was approved by the Ethics Committee of the Health Research Area - FURG (protocol no. 159/2013 23116.005828/2013-85). 
Table 1 Social and economic factors of pregnant and postpartum women treated at a university hospital in southern Brazil $(n=100)$

\begin{tabular}{|c|c|c|c|c|}
\hline Variable & \multicolumn{2}{|c|}{$\begin{array}{l}\text { Sample } \\
(n=100)\end{array}$} & \multicolumn{2}{|c|}{$\begin{array}{l}\text { Reported } \\
\text { some knowl- } \\
\text { edge about } \\
\text { toxoplasmo- } \\
\text { sis } \\
(n=29)\end{array}$} \\
\hline \multicolumn{5}{|l|}{ Age (years) } \\
\hline 14-19 & 30 & $(30 \%)$ & 12 & $(41.4 \%)$ \\
\hline $20-24$ & 25 & $(25 \%)$ & 10 & $(41.7 \%)$ \\
\hline $25-29$ & 18 & $(18 \%)$ & 05 & $(29.4 \%)$ \\
\hline $30-34$ & 18 & $(18 \%)$ & 01 & $(5.6 \%)$ \\
\hline 35 or older & 09 & $(9 \%)$ & 01 & $(11.1 \%)$ \\
\hline \multicolumn{5}{|l|}{ Education } \\
\hline \multicolumn{5}{|l|}{ Elementary } \\
\hline Incomplete & 44 & $(43 \%)$ & 08 & $(19.1 \%)$ \\
\hline Complete & 10 & $(10 \%)$ & 04 & $(40.0 \%)$ \\
\hline \multicolumn{5}{|l|}{ High school } \\
\hline Incomplete & 14 & $(14 \%)$ & 05 & $(35.7 \%)$ \\
\hline Complete & 22 & $(22 \%)$ & 10 & $(47.6 \%)$ \\
\hline \multicolumn{5}{|l|}{ Higher } \\
\hline Incomplete & 08 & $(8 \%)$ & 01 & $(12.5 \%)$ \\
\hline Complete & 02 & $(2 \%)$ & 01 & $(50.0 \%)$ \\
\hline \multicolumn{5}{|c|}{ Family Income (Minimum Wage) } \\
\hline 5 or more & 09 & $(11.4 \%)$ & 05 & $(55.6 \%)$ \\
\hline $2-4$ & 50 & $(63.3 \%)$ & 17 & $(34.0 \%)$ \\
\hline$\leq 1$ & 20 & $(25.3 \%)$ & 07 & $(35.0 \%)$ \\
\hline \multicolumn{5}{|l|}{ Domicile } \\
\hline Periphery & 67 & $(66.0 \%)$ & 23 & $(36.0 \%)$ \\
\hline Center & 08 & $(7.2 \%)$ & 03 & $(42.9 \%)$ \\
\hline Another municipality & 13 & $(13.4 \%)$ & 02 & $(15.4 \%)$ \\
\hline Rural & 08 & $(8.2 \%)$ & 01 & $(12.5 \%)$ \\
\hline Balneary Cassino & 05 & $(5.2 \%)$ & 00 & \\
\hline
\end{tabular}

\section{Results}

The study sample included 29 pregnant women and 71 postpartum women ranging in age from 14 to 41 years. Most participants were aged 14-19 years, and most lived in the outskirts of the city. The mean family income was two to four times the minimum wage, and most participants had not completed elementary school (-Table 1). Of the 100 study participants, 97 had received prenatal care; of these, 80 $(82.5 \%)$ were cared for in the public health care system, and $17(17.5 \%)$ in the private network.

Fifty-six patients reported having some knowledge of toxoplasmosis. Of these, about half (29 patients) reported having received information on toxoplasmosis during prenatal care. Most of these patients were aged between 14 and
19 years, and less than $12 \%$ were older than 30 years. Women cared for in the private health care system (52.9\%) and those with higher educational levels (47.6\%) were more likely to be informed about toxoplasmosis, while those with lower educational levels and those cared for in the public system (25\%) were less likely to be informed. Of the three women who had not received prenatal care, only one reported having knowledge about the disease (-Table $\mathbf{1}$ ).

Most patients who had received prenatal care were unable to respond correctly to questions about toxoplasmosis. Only $15.5 \%(n=15)$ identified the etiologic agent of toxoplasmosis (parasite); $25.8 \%(n=25)$ answered incorrectly that the disease is caused by a virus. Just $3 \%(n=3)$ of women associated the parasitosis with young cats, and $50.5 \%$ ( $n=49$ ) incorrectly answered that toxoplasmosis is associated with cats of all ages. Regarding the modes of transmission of $T$. gondii, only $15.5 \%(n=15)$ correctly identified cross-placental transmission ( - Table 2 ).

Within the group of patients who consulted a health care professional for information during pregnancy, 62\% identified contact with the feces of cats as a risk factor for infection. However, this was below the knowledge level concerning other infection risks such as contact with the soil $(n=3)$, consumption of unwashed vegetables $(n=5)$, consumption of undercooked meat $(n=4)$ and consumption of meat $(n=1)$ (-Table 2). In addition, only $11.1 \%(n=3)$ of these patients answered that toxoplasmosis can have serious complications during pregnancy; $10.3 \%(n=3)$ indicated elevated risk of preterm birth as a potential consequence; and $37.9 \%(n=11)$ recognized the possibility of eye disorders in newborns (-Table 2).

Of the 27 women who reported having acquired knowledge about toxoplasmosis from sources other than a health care professional, 59.2\% $(n=16)$ also identified contact with cat feces as a major risk factor for infection. However, none identified contact with soil and consumption of embedded, two women identified the consumption of poorly sanitized vegetables, and one identified eating raw meat as risk factors (-Table 2). Furthermore, 55.6\% of patients $(n=15)$ could not correctly identify pregnancy complications caused by toxoplasmosis, and only $7.4 \%$ $(n=2)$ identified the possibility of miscarriage. The majority of patients (62.9\%) were unable to identify the sequelae of the disease in children (-Table 2 ).

Forty-nine (50.5\%) of the patients who received prenatal care were unable to identify appropriate preventive measures against toxoplasmosis. In addition, $16.5 \%(n=16)$ reported eliminating stray cats and discarding or donating one's cat during pregnancy as preventive measures. Six of the 16 women who reported discarding their cat as a preventive measure claimed to have received this information during prenatal care (-Table $\mathbf{3}$ ).

Ninety-seven patients responded to questions on dietary intake and other lifestyle variables. Of these, $89.7 \%(n=87)$ consumed sausages, $41.2 \%(n=40)$ consumed raw or undercooked meat, $45.4 \%(n=44)$ had direct contact with the soil, and $23.7 \%(n=23)$ had direct contact with young cats. However, during pregnancy, a smaller percentage $(68 \%, n=66)$ 
Evaluation of Pregnant and Postpartum Women's Knowledge about Toxoplasmosis in Rio Grande Lehmann et al. 541

Table 2 Knowledge of pregnant and postpartum women about etiology, associations, transmission of toxoplasmosis and origin of information received $(n=97)$

\begin{tabular}{|c|c|c|c|c|c|c|c|c|}
\hline \multirow{2}{*}{$\begin{array}{l}\text { Variable } \\
\begin{array}{l}\text { Etiologic agent of } \\
\text { toxoplasmosis }\end{array}\end{array}$} & \multicolumn{2}{|c|}{$\begin{array}{l}\text { Patients had received } \\
\text { prenatal care }(n=97)\end{array}$} & \multicolumn{2}{|c|}{$\begin{array}{l}\text { Patients reported } \\
\text { having received } \\
\text { information during } \\
\text { prenatal care ( } n \\
=29 \text { ) }\end{array}$} & \multicolumn{2}{|c|}{$\begin{array}{l}\text { Patients reported } \\
\text { having acquired } \\
\text { knowledge from other } \\
\text { sources }(n=27)\end{array}$} & \multicolumn{2}{|c|}{$\begin{array}{l}\text { Patients without } \\
\text { information }(n=41)\end{array}$} \\
\hline & $n$ & $\%$ & $n$ & $\%$ & $n$ & $\%$ & $n$ & $\%$ \\
\hline Parasite & 15 & 15.5 & 6 & 40 & 6 & 40 & 3 & 20 \\
\hline Virus & 25 & 25.8 & 12 & 48 & 4 & 16 & 9 & 36 \\
\hline Poison & 1 & 1.03 & 0 & 0 & 1 & 100 & & \\
\hline No answer & 56 & 57.7 & 11 & 19.7 & 16 & 28.6 & 29 & 51.7 \\
\hline \multicolumn{9}{|c|}{ Toxoplasmosis is associated with } \\
\hline Cats of all ages & 49 & 50.5 & 20 & 40.8 & 19 & 38.8 & 10 & 20.4 \\
\hline Young cats & 3 & 3.01 & 1 & 33.3 & 1 & 33.3 & 1 & 33.3 \\
\hline Adult cats & 0 & 0 & & & & & & \\
\hline Stray cats & 4 & 4.1 & 4 & 100 & & & & \\
\hline Dogs of all ages & 0 & 0 & & & & & & \\
\hline Young dogs & 1 & 1.03 & 1 & 100 & & & & \\
\hline Adult dogs & 0 & 0 & & & & & & \\
\hline No answer & 40 & 41.2 & 3 & 7.5 & 7 & 17.5 & 30 & 75 \\
\hline \multicolumn{9}{|c|}{ Toxoplasmosis is transmitted by } \\
\hline Having a cat at home & 12 & 12.4 & 5 & 41.7 & 4 & 33.3 & 3 & 25 \\
\hline Cat feces & 40 & 41.2 & 18 & 45 & 16 & 40 & 6 & 15 \\
\hline $\begin{array}{l}\text { Changing the cat litter } \\
\text { box }\end{array}$ & 7 & 7.2 & 4 & 57.1 & 0 & 0 & 3 & 42.9 \\
\hline $\begin{array}{l}\text { Feces from dogs and } \\
\text { cats }\end{array}$ & 11 & 11.3 & 6 & 54.5 & 2 & 18.2 & 3 & 27.3 \\
\hline Dog feces & 0 & 0 & 0 & 0 & 0 & 0 & & 0 \\
\hline $\begin{array}{l}\text { Changing the dog lit- } \\
\text { ter box }\end{array}$ & 0 & 0 & 0 & 0 & 0 & 0 & & 0 \\
\hline Animal hair (dog/cat) & 12 & 12.4 & 5 & 41.7 & 3 & 25 & 4 & 33.3 \\
\hline $\begin{array}{l}\text { Contact with soil } \\
\text { (gardening) }\end{array}$ & 3 & 3.1 & 3 & 100 & & & & \\
\hline $\begin{array}{l}\text { Contact with sick } \\
\text { person }\end{array}$ & 1 & 1.03 & & & 1 & 100 & & \\
\hline $\begin{array}{l}\text { Consumption of } \\
\text { undercooked meat }\end{array}$ & 9 & 9.3 & 8 & 88.9 & 1 & 11.1 & & \\
\hline Handling raw meat & 4 & 4.1 & 4 & 100 & & & & \\
\hline $\begin{array}{l}\text { Consumption of } \\
\text { sausages }\end{array}$ & 1 & 1.03 & 1 & 100 & & & & \\
\hline $\begin{array}{l}\text { Consumption of } \\
\text { unwashed vegetables }\end{array}$ & 6 & 6.2 & 5 & 83.3 & 1 & 16.7 & & \\
\hline $\begin{array}{l}\text { Transmitted via } \\
\text { placenta }\end{array}$ & 15 & 15.5 & 7 & 46.6 & 4 & 26.7 & 4 & 26.7 \\
\hline No answer & 40 & 41.2 & 4 & 10 & 9 & 22.5 & 27 & 67.5 \\
\hline
\end{tabular}


Table 3 Knowledge of pregnant and postpartum women about preventive measures of toxoplasmosis and origin of information received $(n=97)$

\begin{tabular}{|c|c|c|c|c|c|c|c|c|}
\hline \multirow[t]{2}{*}{$\begin{array}{l}\text { Variable } \\
\text { Modes of prevention: }\end{array}$} & \multicolumn{2}{|c|}{$\begin{array}{l}\text { Patients had } \\
\text { received prenatal } \\
\text { care }(n=97)\end{array}$} & \multicolumn{2}{|c|}{$\begin{array}{l}\text { Patients reported } \\
\text { having received } \\
\text { information during } \\
\text { prenatal care } \\
(n=29)\end{array}$} & \multicolumn{2}{|c|}{$\begin{array}{l}\text { Patients reported } \\
\text { having acquired } \\
\text { knowledge from } \\
\text { other sources } \\
(n=27)\end{array}$} & \multicolumn{2}{|c|}{$\begin{array}{l}\text { Patients without } \\
\text { information } \\
(n=41)\end{array}$} \\
\hline & $n$ & $\%$ & $n$ & $\%$ & $n$ & $\%$ & $n$ & \\
\hline $\begin{array}{l}\text { Discard/donate } \\
\text { cat when finding } \\
\text { out about pregnancy }\end{array}$ & 16 & 16.5 & 6 & 37.5 & 5 & 31.3 & 5 & 31.2 \\
\hline $\begin{array}{l}\text { Feed the cat with } \\
\text { processed cat food }\end{array}$ & 5 & 5.2 & 2 & 40 & 1 & 20 & 2 & 40 \\
\hline $\begin{array}{l}\text { Do not let the cat } \\
\text { eat rodents }\end{array}$ & 7 & 7.2 & 4 & 57.1 & & & 3 & 42.9 \\
\hline Avoid stray cats & 16 & 16.5 & 9 & 56.3 & 2 & 12.5 & 5 & 31.2 \\
\hline Avoid stray dogs & 3 & 3.1 & 2 & 66.7 & & & 1 & 33.3 \\
\hline $\begin{array}{l}\text { Let someone else } \\
\text { change the cat litter box }\end{array}$ & 9 & 9.3 & 4 & 44.4 & 1 & 11.2 & 4 & 44.4 \\
\hline Not having pets at home & 11 & 11.3 & 3 & 27.3 & 5 & 45.4 & 3 & 27.2 \\
\hline Eat well-cooked meat & 16 & 16.5 & 12 & 75 & 1 & 6.3 & 3 & 18.7 \\
\hline Wash fruits and vegetables & 19 & 19.6 & 11 & 57.9 & 4 & 21.05 & 4 & 21.05 \\
\hline $\begin{array}{l}\text { Clean utensils and } \\
\text { cutting boards after } \\
\text { using them in food } \\
\text { preparation }\end{array}$ & 10 & 10.3 & 7 & 70 & 0 & & 3 & $(30.0)$ \\
\hline No answer & 49 & 50.5 & 6 & 12.2 & 15 & 30.6 & 28 & 57.2 \\
\hline
\end{tabular}

reported consumption of sausages, and $30.9 \%(n=30)$ reported consuming raw or undercooked meat. Of the 29 patients who had received information during prenatal consultations, a smaller proportion consumed these foods (24.2\% [ $n=16]$ and $13.3 \%$ [ $n=4$ ] respectively). In contrast, of the 27 women who reported receiving information from another source, $27.3 \%$ ( $n=18)$ consumed sausages, and $26.7 \%(n=8)$ consumed raw or undercooked meat during pregnancy.

Analysis of data from medical records showed that $52.6 \%$ $(n=51)$ of the participants did not have serology results (IgG) for $T$. gondii. Of the 46 patients who underwent serologic testing, $65.2 \%(n=30)$ were seronegative for toxoplasmosis, and $34.8 \%$ ( $n=16)$ were positive for IgG. Only one woman had a positive IgM result. Seronegative patients received information about parasitosis during prenatal visits more frequently than seropositive patients (76.7\% versus $37.5 \%$ ).

\section{Discussion}

Health care professionals are responsible for educating women about the importance of prenatal care and for improving health promotion, prevention, and treatment of diseases during pregnancy to meet individual and community health care needs. ${ }^{13}$ Educational nursing activities to assist women may reduce the incidence of preventable disease and help women protect their own health and the health of their newborns. ${ }^{14}$ Epidemiological studies have shown the importance of providing guidance to pregnant women about preventive behaviors. ${ }^{12}$ While almost all of the pregnant and postpartum women who participated in this study received prenatal care, only 53.7\% said they had received information about toxoplasmosis during the prenatal period. Thus, it is critical that health care professionals working in prenatal care are appropriately educated so that they can provide accurate information to patients about avoiding primary infection. ${ }^{9}$

Participants with higher levels of education and those who underwent follow-up in the private health care sector were most likely to receive information about toxoplasmosis during their prenatal care. However, most of the study participants used the public health care system. In a study of 29 doctors and nurses providing prenatal care in the city of Rio Grande, $58.7 \%$ of those surveyed reported providing guidance to pregnant women regarding toxoplasmosis. However, only $6.9 \%$ knew the correct procedures to follow with IgM reagents for pregnant women. ${ }^{15}$ Other studies also point to the failure of health care providers to give pregnant women sufficient information about parasites for appropriate self-care measures. ${ }^{16-18}$ Patients older than 30 years were least likely to have received information about parasitosis, whereas younger patients were most likely to receive such information.

The majority of the study participants were unaware of the cause, risk factors, major modes of transmission, 
symptoms, or modes of prevention of toxoplasmosis. In another study in which a similar survey was administered, general knowledge of parasitosis was also low (less than $10 \%) .{ }^{11}$ These findings indicate the importance of educating pregnant women and the community in general about preventive measures. ${ }^{9,19,20}$ In a study of pregnant and postpartum women in three Asian countries, $19.4 \%$ of respondents correctly identified contact with cat feces as the main mode of transmission of toxoplasmosis. ${ }^{11}$ This proportion is similar to that found in our study. However, oocysts do not become infective in feces but rather in the soil, although the possibility of direct transmission from feces does exist. Despite usage of the term "mode of transmission by contact with cat feces" and reports of environmental contamination caused by the feces of infected cats, one of the main risks of infection is through the handling of cat litter boxes. It should be noted that it is inaccurate to say that cats are the main source of infection. ${ }^{12}$

Most of the women in our study were unaware that toxoplasmosis infection can be caused by ingestion of contaminated food. Studies show that infection in humans can be caused by ingestion of raw or undercooked meat containing tissue cysts or uncooked vegetables contaminated with oocysts. ${ }^{21,22}$ Such transmission can be prevented by simple measures, including cooking meat properly, washing fruits and vegetables, and not feeding raw or undercooked meat to cats. ${ }^{9}$ Prevention of toxoplasmosis is important in the control of parasitic diseases, ${ }^{9}$ and the hygiene and dietary practices of pregnant women form an essential component of the prevention efforts. ${ }^{23}$

This study showed a substantial absence of preventive practices to reduce toxoplasmosis infection. Even among women who had received information from a health care professional, $37.5 \%$ believed discarding one's cat to be an effective preventive measure. However, it is important to note that approximately half of the participants correctly identified the proper cooking of meat and cleaning of vegetables as important preventive measures. Patients receiving information through prenatal care reported consuming processed meats and raw or undercooked meat less often than women who received information from another source. This suggests that the communication of health care information should be prioritized in prenatal care, because the exchange of information and experience may be the best way to promote the understanding of the process of pregnancy and prenatal health care concerns. ${ }^{24}$ Improving knowledge of preventive measures and appropriate behavioral changes can reduce infection rates. ${ }^{11}$

Investigation of the prevalence of infectious diseases in different regions is essential to create health care policies and programs that can effectively improve care and public awareness to prevent or minimize the occurrence of new cases. ${ }^{25}$ Only half $(46 / 97)$ of the patients in our study had been serologically tested for toxoplasmosis. This is an important finding, because serological tests for detection of IgG and $\operatorname{IgM}$ antibodies against $T$. gondii is a recommended component of prenatal care in most regions of the country. ${ }^{24}$

Not surprisingly, the study showed that seronegative patients were most likely to have received information about parasitosis during prenatal visits. However, studies show that reinfection can occur in seropositive patients; ${ }^{4}$ thus, it is important that guidelines are adhered to for all pregnant women. This includes serological monitoring and guidance for pregnant and postpartum women. ${ }^{5}$

Some procedures set by the Brazilian Ministry of Health regarding guidance provided during prenatal care are no longer performed by professionals working in this area. Appropriate training of these professionals for prenatal consultations is a priority. ${ }^{26}$ Through such training, health care professionals can acquire the skills necessary to conduct consultations that fully meet the needs of pregnant women. Therefore, relevant professional training should continue in order to provide quality care. ${ }^{27}$

In addition, it is imperative that nurses and doctors providing prenatal care are trained to request appropriate laboratory tests to establish the serologic profile of pregnant women and, if necessary, provide timely treatment. ${ }^{9}$

\section{Conclusions}

Our study shows the strong cultural link between toxoplasmosis and cats. Although these two are indeed closely linked, it has been shown that other sources of infection are more common than contact with cats. This demonstrates the importance of strengthening patient guidance during the prenatal period. The conceptualization of health care must move away from a unidirectional model of providing care and information to a model of dialogue that supports knowledge exchange between health care professionals and patients.

Education and awareness among health care professionals, pregnant women, and the community at large are crucial priorities, not only for toxoplasmosis or other parasitic infections, but also for health issues and diseases more broadly. Accordingly, the authors recommend that health care professionals perform consistent educational activities, including the distribution of information indirectly (via pamphlets or banners), and that they participate in the promotion of community health care activities.

\section{Acknowledgments}

We thank the Post-graduate Program in Health Sciences, the Coordenação de Aperfeiçoamento de Pessoal de Nível Superior (CAPES), and the professionals from the center of obstetrics of the University Hospital of the city of Rio Grande (FURG) for their important contributions for the development of the study.

\section{References}

1 Hill DE, Chirukandoth S, Dubey JP. Biology and epidemiology of Toxoplasma gondii in man and animals. Anim Health Res Rev 2005;6(1):41-61

2 Dubey JP. The history of Toxoplasma gondii-the first 100 years. J Eukaryot Microbiol 2008;55(6):467-475

3 Ferezin RI, Bertolini DA, Demarchi IG. [Prevalence of positive sorology for HIV, hepatitis $\mathrm{B}$, toxoplasmosis and rubella in 
pregnant women from the northwestern region of the state of Paraná]. Rev Bras Ginecol Obstet 2013;35(2):66-70 Portuguese

4 Montoya JG, Liesenfeld O. Toxoplasmosis. Lancet 2004;363(9425): 1965-1976

5 Remington JS, McLeod R, Thulliez P, Desmonts G. Toxoplasmosis. In: Remington JS, Klein JO, Wilson CB, Baker CJ, editors. Infectious diseases of the fetus and newborn infant. 6th ed. Philadelphia: Elsevier Saunders; 2006. p. 947-1091

6 Kasper LH. Infecção por Toxoplasma. In: Braunwald E, Fauci AS, Kasper DL, Hauser SL, Longo DL, Jameson JL, editores. Harrison medicina interna. 15a ed. Rio de Janeiro: McGraw-Hill; 2002. p. $1294-9$

7 Ocampo LM, Duarte-Gandica I. [A model of congenital toxoplasmosis transmission dynamics]. Rev Salud Publica (Bogota) 2010; 12(2):317-326 Spanish

8 Sáfadi MA. Toxoplasmose. Pediatr Mod 2000;36(1/2):9-19

9 Branco BH, Araújo SM, Falvigna-Guilherme AL. [Primary prevention of toxoplasmosis: knowledge and attitudes of health professionals and pregnant women of public service of Maringá, Paraná state, Brazil]. Sci Med. 2012;22(4):185-190 Portuguese

10 Kravetz JD, Federman DG. Prevention of toxoplasmosis in pregnancy: knowledge of risk factors. Infect Dis Obstet Gynecol 2005; 13(3):161-165

11 Andiappan H, Nissapatorn V, Sawangjaroen N, et al. Comparative study on Toxoplasma infection between Malaysian and Myanmar pregnant women. Parasit Vectors 2014;7:564

12 Cademartori BG, Farias NA, Rod CS. [Seroprevalence and risk factors to Toxoplasma gondii infection in pregnant women of Pelotas, south of Brazil]. Rev Panam Infectol. 2008;10(4):30-35 Portuguese

13 Martins JS, Dantas FA, Almeida TF, Santos MB. A assistência de enfermagem no pré-natal: enfoque na estratégia da saúde da família. Rev Uniabeu. 2012;5(9):278-288

14 Marques RG, Almeida Prado SR. Consulta de enfermagem no prénatal. Rev Enferm UNISA. 2004;5:33-36

15 Gonçalves CV, Kerber NP, Backes AP, Alves CB, Wachholz VA, Oliveira FS. Knowledge about laboratorial routine requested by professionals in Basic Care: a descriptive study. Online Braz J Nurs. 2013;12(4):813-822
16 Ziemba J, Nowakowska-Głab A, Wilczyński J, Maniecka-Bryła I, Nowakowska D. [Knowledge of toxoplasmosis among pregnant women, midwifes, medical students and obstetricians]. Med $\mathrm{Pr}$ 2010;61(3):271-276 Polish

17 Alvarado-Esquivel C, Sifuentes-Álvarez A, Estrada-Martínez S, Rojas-Rivera A. [Knowledge and practices on toxoplasmosis in physicians attending pregnant women in Durango, Mexico]. Gac Med Mex 2011;147(4):311-324 Spanish

18 da Silva LB, de Oliveira RdeV, da Silva MP, Bueno WF, Amendoeira MR, de Souza Neves E. Knowledge of toxoplasmosis among doctors and nurses who provide prenatal care in an endemic region. Infect Dis Obstet Gynecol 2011;2011:750484

19 Elsheikha HM. Congenital toxoplasmosis: priorities for further health promotion action. Public Health 2008;122(4):335-353

20 Amin TT, Ali MN, Alrashid AA, Al-Agnam AA, Al Sultan AA. Toxoplasmosis preventive behavior and related knowledge among Saudi pregnant women: an exploratory study. Glob J Health Sci 2013;5(5):131-143

21 Dubey JP, Lindsay DS, Speer CA. Structures of Toxoplasma gondii tachyzoites, bradyzoites, and sporozoites and biology and development of tissue cysts. Clin Microbiol Rev 1998;11(2):267-299

22 Liu Q Wei F, Gao S, et al. Toxoplasma gondii infection in pregnant women in China. Trans R Soc Trop Med Hyg 2009;103(2):162-166

23 Centers of Disease Control and Prevention [Internet]ParasitesToxoplasmosis (Toxoplasma infection). 2013 [cited 2014 Aug 01]. Available from: <http://www.cdc.gov/toxoplasmosis/>

24 Brasil. Ministério da Saúde [Internet].Assistência pré-natal: manual técnico. Brasília (DF): Ministério da Saúde. 2000 [citado 2015 Aug 05]. Disponível em: <http://bvsms.saude.gov.br/bvs/publicacoes/cd04_11.pdf>

25 Alves JAB, Oliveira LAR, Oliveira MFB, et al. Prevalência de anticorpos anti-toxoplasma gondii em mulheres grávidas. Rev Enferm UERJ. 2009;17(1):107-110

26 Araujo SM, Silva ME, Moraes RC, Alves DS. A importância do prénatal e a assistência de enfermagem. VEREDAS FAVIP - Revista Eletrônica de Ciências 2010;3(2):61-67

27 Figueiredo GLA, de Mello DF. [Nursing practice in the health care of children at a basic health unit]. Rev Lat Am Enfermagem 2003; 11(4):544-551 Portuguese 